\title{
Evaluation of new kits for the assessment in vitro of thyroid function by determination of serum total thyroxine, free TBG capacity, and free thyroxine index using Sephadex G-25 and ${ }^{125}$ I-labelled triiodothyronine and thyroxine
}

\author{
P. J. N. HOWORTH AND C. G. McKERRON
}

From the Departments of Chemical Pathology and Medicine, King's College Hospital Medical School, London

SYNOPSIS A trial was carried out on 134 patients of new kits (Ames Co) using columns of Sephadex G-25 for the determination of serum total thyroxine (Tetralute test) and for the indirect estimation of serum free thyroxine-binding globulin capacity (Trilute test). Both new methods were quicker and easier than the reference resin methods and of similar precision. The two measurements when combined to give a free thyroxine index (Trilute-Tetralute-FTI) increased further the diagnostic discrimination and usefulness of the tests.

The method for the determination of serum thyroxine can be modified to give a direct estimate of serum free thyroxine, expressed as a free thyroxine index. This new single-column technique, called the 'single-column free thyroxine index', gave a good correlation with clinical thyroid status in a preliminary trial of 45 patients.

The sharply rising demand on clinical chemistry laboratories for thyroid function tests in vitro has led to the development of new tests simple enough for use with large numbers of sera. Several commercially produced kits are available for the indirect estimation of the serum free thyroxine-binding (TBG) capacity. These are often termed $T_{3}$ (L-3,5, 3 'triiodothyronine) uptake tests. It has, however, proved more difficult to develop simple yet precise and accurate methods for the determination of serum total $\mathrm{T}_{4}$ (L-thyroxine); most current methods still require either a solvent or ion-exchange resin extraction of serum.

The dextran polymergel Sephadex G-25(Pharmacia Ltd) has long been used for thyroid function tests in vitro such as the indirect estimation of serum free TBG capacity (Shapiro and Rabinowitz, 1962; Cuarón and Fucugauchi, 1964; Hansen, 1964; Gimlette, 1967); serum total $\mathbf{T}_{4}$ (Lissitzky and Bismuth, 1963; Murphy and Pattee, 1964) and free $\mathrm{T}_{4}$ (Lee, Henry, and Golub, 1964; Liewendahl and Lamberg, 1965). Sephadex G-25 has now been Received for publication 1 November 1973. utilized to give a simple direct method without solvent extraction for the determination of serum total $\mathbf{T}_{4}$ (Bauer, Schick, Phillips, Rupe, Gross, and Gordon, 1970; Braverman, Vagenakis, Foster, and Ingbar, 1971). It can also be used for the indirect estimation of serum free TBG capacity, and the two results combined to give a conventional free thyroxine index (FTI). Moreover, the technique for the determination of serum total $\mathbf{T}_{4}$ can be modified, using the principle of the "effective thyroxine ratio" (Mincey, Thorson, and Brown, 1971), to give a direct estimate of serum free thyroxine as a free thyroxine index, referred to as the 'single-column free thyroxine index'.

We describe here the new Sephadex G-25 kits (Ames Co) and report an evaluation of their use for the determination of serum total $T_{4}$ (Tetralute based on the method of Bauer et al, 1970) and the indirect estimation of serum free TBG capacity (Trilute based on the method of Shapiro and Rabinowitz, 1962), together with a preliminary evaluation of the new single-column free thyroxine index. 


\section{Clinical Material}

Sera were obtained from 134 patients at King's College Hospital under the care of the Medical Unit, on whom primary diagnostic thyroid function tests in vitro had been requested. Patients being treated for previously diagnosed thyroidal illness were excluded from the trial. Clinical thyroid status was established by one of us (C.G.M.) with another experienced member of the Endocrine Clinic. Sera were separated from clotted blood within three $\mathrm{hr}$ of collection and stored at $-20 \mathrm{C}$ until analysed.

\section{Principle of the Methods}

Aromatic compounds such as the thyronines $T_{3}$ and $T_{4}$ have an affinity for the bed material of the cross-linked polysaccharide gels used in Sephadex (Gelotte, 1960). Other molecules such as proteins and free iodide may be eluted from the gel by water or buffers (Porath and Flodin, 1959). Adsorbed thyronines may subsequently be displaced from the gel onto TBG by elution with serum.

1 SEPHADEX T 3 -UPTAKE (TRILUTE)

Fifty $\mu \mathrm{l}$ serum is equilibrated with $0.5 \mathrm{ml}{ }^{125} \mathrm{I}_{-} \mathrm{T}_{3}$ reagent in phosphate buffer of $\mathrm{pH} 4 \cdot 8$, to allow for the added $\mathrm{T}_{3}$ to be taken up on the protein-binding sites. This equilibration is conveniently carried out above the Sephadex columns (external dimension $16 \times 65 \mathrm{~mm}$ : dimension of Sephadex gel $12 \times 19$ $\mathrm{mm}$ ). The amount of ${ }^{125} \mathrm{I}-\mathrm{T}_{3}$ added (about $2 \mathrm{ng}$ ) is comparable to the $T_{4}$ content of $50 \mu \mathrm{l}$ of a normal serum. The serum-buffer- ${ }^{125} \mathrm{I}_{-} \mathrm{T}_{3}$ mixture is then run through the column (flow rate $0.5 \mathrm{ml} / \mathrm{min}$ ) after which the entire column is transferred to a gamma counter

for an initial count of the ${ }^{125}{ }^{25}-T_{3}$ to be made. The Ames Thyrimeter gamma counter is specifically designed to count the Sephadex columns, but any ordinary gamma counter can be used provided it counting geometry is acceptable. Serum proteins (containing ${ }^{125} \mathrm{I}_{-} \mathrm{T}_{3}$ bound to TBG) and any frees ${ }^{125}$ I-iodide are then eluted with $3 \mathrm{ml}$ distilled water $\overline{\bar{p}}$. leaving free ${ }^{125} \mathrm{I}_{-} \mathrm{T}_{3}$ adsorbed onto the column. final count of column ${ }^{125} \mathrm{I}_{-} \mathrm{T}_{3}$ is made. The percent age retention of ${ }^{125} \mathrm{I}-\mathrm{T}_{3}$ on the column is proportion $-\mathrm{s}$ al to the percentage saturation of the TBG in the original serum, ie, inversely proportional to the serum free TBG capacity. The results are expressed directly not as a percentage of the retention of pooled normal serum (as are most other uptake kits).

2 SERUM TOTAL T 4 (TETRALUTE)

More than $95 \%$ of the $T$ content of serum can $\omega$ freed from TBG by mixing with $0.1 \mathrm{~mol}$ sodium hydroxide, pH 13 (Mougey and Mason, 1963). Aboutm $2 \mathrm{ng}{ }^{125} \mathrm{I}_{-} \mathrm{T}_{4}$ in $0.5 \mathrm{ml} 0.1 \mathrm{~mol} \mathrm{NaOH}$ is mixed witlo $0.1 \mathrm{ml}$ serum on top of a Sephadex column at $\mathrm{pH}$ 13 (fig 1); the alkali releases serum $T_{4}$ by denaturate ing the binding proteins. The mixture is run through the column to adsorb the $T_{4}$ and ${ }^{125} \mathrm{I}-\mathrm{T}_{4}$, and ${ }_{\mathrm{O}} \mathrm{N}_{\mathrm{P}}$ column is then washed with $4 \mathrm{ml} 0.075 \mathrm{~mol}$ barbitố buffer pH 8.6 in order to elute any free ${ }^{125}$ I-iod and the serum proteins (which now contain $<$ of their original $\mathrm{T}_{4}$ ) and to reconstitute a $\mathrm{pH}$ a which serum-binding proteins are active. Sufficien TBG is then run through the column to displace about two-thirds of the adsorbed $T_{4}$ and ${ }^{125} \mathrm{I}-\mathrm{T} \overrightarrow{\overrightarrow{2}}$ from the column using $1 \mathrm{ml}$ of a serum preparation in barbitone buffer $\mathrm{pH} 8 \cdot 6$. The exact composition of this eluting reagent ("lyophilized human globulins"

\section{STAGE 3}

STAGE I

$100 \mu 1$ serum $\&^{125_{1-T_{4}}}$

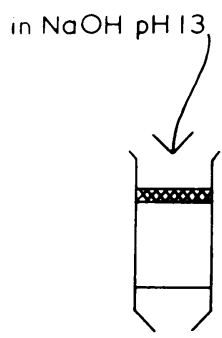

STAGE 2

Barbitone buffer

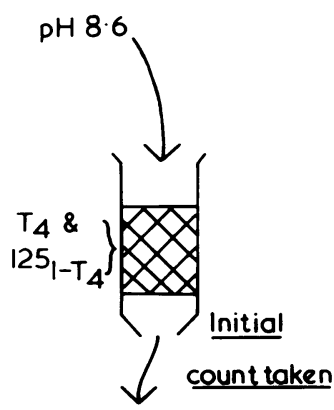

Serum proteins minus $\mathrm{T}_{4}$
Eluting serum(free TBG)

in barbitone $\mathrm{pH} \mathrm{8.6,}$

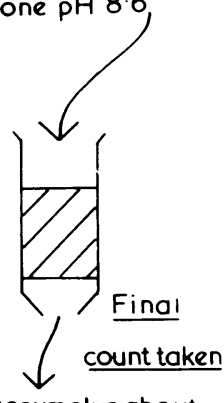

Eluting serumplus about

$2 / 3$ adsorbed $T_{4} \&^{125} /-T_{4}$
Fig 1 Outline of the method for the Sephadex $G-25$ determination of serum total thyroxine. 
is not disclosed by the manufacturers, but a similar displacement of $T_{4}$ can be achieved by $0.5 \mathrm{ml}$ of a $1 / 10$ dilution of normal pooled human serum in $0 \cdot 1$ mol barbitone buffer, $\mathrm{pH} 8 \cdot 6$. The TBG-bound $\mathrm{T}_{4}$ and ${ }^{125} \mathrm{I}_{-} \mathrm{T}_{4}$ are washed off the column by $4 \mathrm{ml}$ barbitone buffer. The $T_{4}$ from the serum competes with the ${ }^{125} \mathrm{I}_{-} \mathrm{T}_{4}$ for the limited amount of TBG; hence, the larger the amount of serum $T_{4}$, the less ${ }^{125} \mathrm{I}_{-} \mathrm{T}_{4}$ will bind to TBG and the more will be retained on the column. The column is counted before and after elution and the latter count expressed as a percentage of the former (percentage retention). A standard curve is made by treating similarly different volumes of a standard serum of known $\mathrm{T}_{4}$ content and plotting percentage retention against $T_{4}$ (fig 2 ).

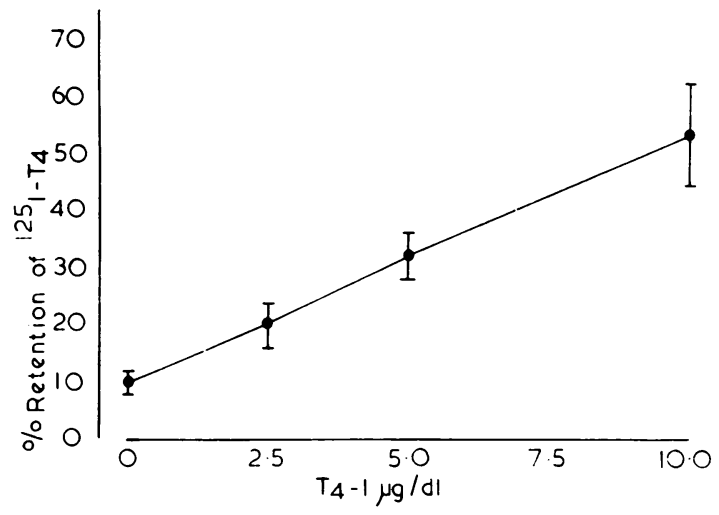

Fig 2 Tetralute serum $T_{4}$ determination: \% retention of ${ }^{125} I-T_{4}$ mean $\pm S D$ against ng $T_{4}-I$ for 20 standard curves.

3 FREE THYROXINE INDEX

The serum free $T_{4}$ concentration may be estimated indirectly as an index (Clark and Horn, 1965) or factor (Osorio, Jackson, Gartside, and Goolden, 1962). The FTI is the product of serum $T_{4}$ concentration and serum free TBG capacity, normally derived from an uptake test expressed as a ratio $\frac{\% \text { test serum uptake }}{\% \text { control serum uptake }}$; in the present trial, the Trilute-Tetralute FTI $=$ serum total $\mathrm{T}_{4} \mu \mathrm{g} / \mathrm{d}_{1}$ (Tetralute) $\times \frac{\text { Trilute } \% \text { retention, }}{100}$ and the limits differ from those of other free thyroxine indices.

\section{Methods}

Sera were analysed in batches of 10 to 20 which always included a quality control serum. The first 120 sera were analysed in duplicate.

For comparison the sera were also analysed by established reference methods using resin for $T_{4^{-}}$uptake, total $T_{4}$ and the $T_{4}$-FTI. The methods were those of Maclagan and Howorth (1969) as published except for the following modifications.

For the $\mathrm{T}_{4}$ uptake test add $0.1 \mathrm{ml}$ serum (Beckman Spinco micropipette) to the $2 \mathrm{ml}$ working ${ }^{125} \mathrm{I}_{-} \mathrm{T}_{4}$ solution after the initial count and mix. Add $2 \mathrm{ml}$ barbitone buffer $\mathrm{pH} 8.6$ and mix to give a final dilution of serum $1 / 41$. The pool serum content in the serum $\mathrm{T}_{4}$ determination was similarly altered. Resin uptake was carried out for 25 to 35 min at room temperature, the time being varied according to ambient room temperature. The resin volume per tube was reduced to $0.35 \mathrm{ml}$. The effect of these changes on the resin uptake system has been to alter the range and sensitivity of the $T_{4}$-uptake test, and thereby also the range for the $\mathrm{T}_{4}$-FTI (table II).

Serum PBI also was estimated on many sera by a standard AutoAnalyzer (Technicon) technique in which sera were not pretreated with a resin.

\section{Results}

The following patients were tested: 52 euthyroid women, mean age $47.5 \pm 15.9$ (range 18-82 years); eight euthyroid women, either pregnant or taking oral contraceptive tablets; 12 euthyroid men, mean age $49.0 \pm 15.5$ (range 20-76 years); 14 'sick euthyroid' inpatients, mean age $50.3 \pm 8.3$ (range $41-70$ years); 31 thyrotoxic patients, mean age 47.5 \pm 18.7 (range 13-84 years); and 17 hypothyroid patients, mean age $56 \cdot 1 \pm 17 \cdot 2$ (range $15-82$ years).

Results and a statistical analysis are given in table I. Figure 2 gives mean values \pm SD for 20 standard curves for the Tetralute serum $T_{4}$ determinations. Figures 3-6 compare results by the method under evaluation against the reference method. Table II gives the normal working ranges for the methods (selected to include $80 \%$ of normals -see below), derived from analysis of the results given in figs 3-6, together with the percentage of euthyroid patients with results outside these limits and corresponding percentages of patients with abnormal thyroid status having results inside these limits.

The normal working precision of the Trilute and Tetralute methods was calculated both from differences in duplicate analyses (within-batch variation) and from results obtained on quality control sera (between-batch variation). Results are shown in table III. The reference $\mathrm{T}_{4}$ method has a coefficient of variation of $9.1 \%$ within-batch $(10.8 \%$ 


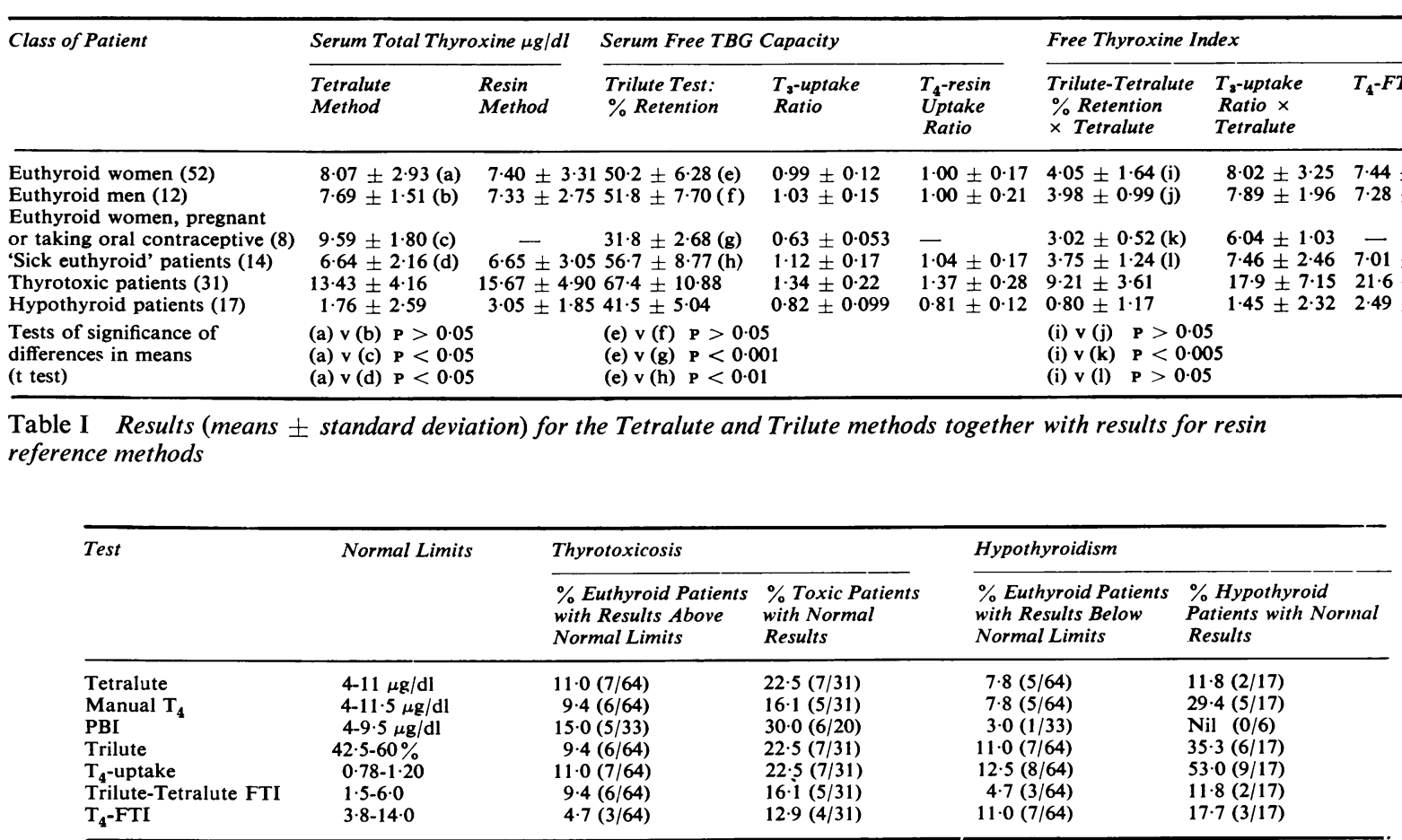

Table II Normal working ranges for the methods together with \% results outside these limits according to clinical thyroid status

\begin{tabular}{llcl}
\hline Method & & Within Batch & Between Batch \\
\hline Trilute & Mean & $57 \cdot 0 \%$ & $79 \cdot 2 \%$ \\
& SD & $2 \cdot 84$ & $3 \cdot 56$ \\
& CV & $5 \cdot 0 \%$ & $4 \cdot 5 \%$ \\
Tetralute & n & 120 & 31 \\
& Mean & $9 \cdot 0 \mu \mathrm{g} / \mathrm{dl}$ & $14 \cdot 8 \mu \mathrm{g} / \mathrm{dl}$ \\
& SD & $0 \cdot 68$ & $1 \cdot 66$ \\
& CV & $7 \cdot 6 \%$ & $11 \cdot 2 \%$ \\
& n & 112 & 27 \\
\hline
\end{tabular}

Table III Precision of the Trilute and Tetralute methods

between-batch) and the reference $\mathrm{T}_{4}$-uptake test $6.8 \%$ within-batch (Howorth, 1970).

The mean serum $\mathrm{T}_{4}$ concentrations found in the various classes of patients by the resin method and the Tetralute column method were analysed for significance in difference ( $t$ tests); none of the observed differences in means were significant at the $5 \%$ level.

DISCUSSION ON THE TRILUTE AND TETRALUTE METHODS

We can consider the Trilute and Tetralute thyroid function tests in vitro from the viewpoints of both clinician and chemical pathologist. The clinician is concerned with their usefulness compared with existing tests, whilst the pathologist must also consider technicalities such as precision, simplicity, suitability for mechanization, as well as cost.

With most thyroid function tests an overlap is found between results from clinically abnormal and clinically euthyroid patients. This overlap can be artificially reduced by exclusion from a trial of difficult or borderline cases, or by listing such results separately, but this was not done in the present work. It is our view that, since so many patients referred to an endocrine clinic with suspected thyroid disease are middle-aged women (mean age for both euthyroid women and all thyrotoxic patients was 47.5 years), then the normal limits are best derived from results obtained in euthyroid women in this age group. The actual normal limits were taken at convenient figures so that only about one result in five lay outside the limits. Use of conventional ' $95 \%$ ranges' would give rise to an unacceptably high proportion of normal results in clinically abnormal patients.

The normal limits thus derived for the Tetralute serum $\mathrm{T}_{4}$ determination of $4-11 \mu \mathrm{g} / \mathrm{dl}$ are the same as those used by earlier workers using the TBG- 


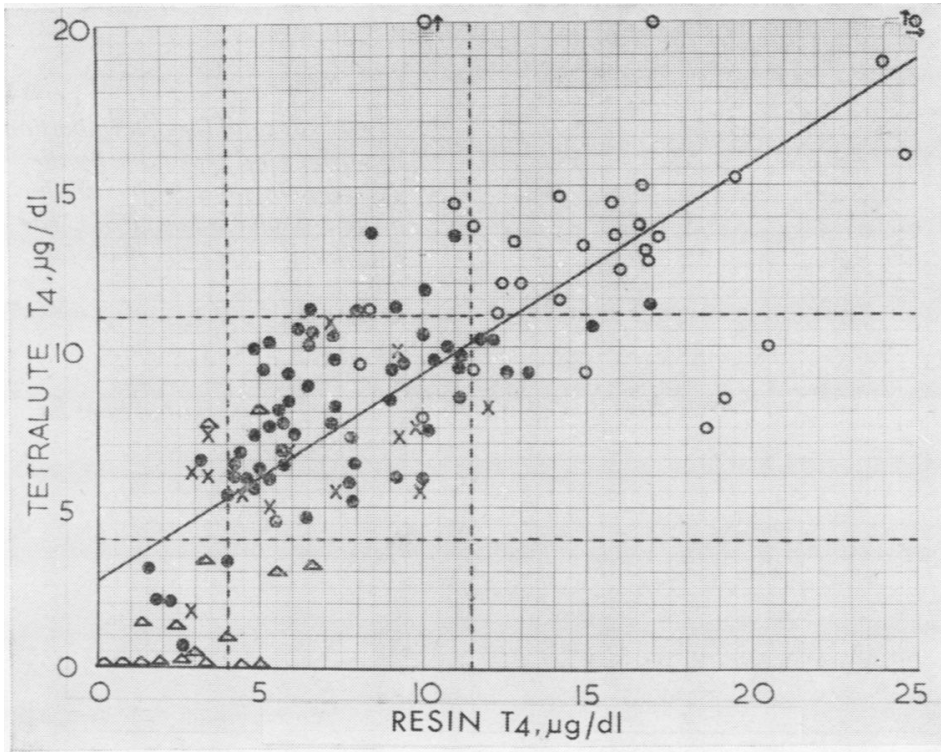

Fig 3 Results for determination of serum total thyroxine by the Tetralute method against those by the resin reference method. The calculated regression line is shown: $y=0.65$ $x+2.67 ; \mathrm{SE}(y)=3.06 ; \mathrm{r}=0.759$; $\mathrm{n}=126$.

Normal ranges are indicated by the dotted lines.

$\bigcirc=$ thyrotoxic patient

$=$ euthyroid patient

$\triangle=$ hypothyroid patient

$\times=$ 'sick euthyroid' patient

displacement technique (Murphy, Pattee, and Gold, 1966; Howorth and Maclagan, 1969) but are different from those of 5.7-13.0 $\mu \mathrm{g} / \mathrm{dl}$ given in the Ames Company literature. The Tetralute test gave better diagnostic discrimination than the resin $T_{4}$ test in hypothyroidism (fig 3 and table II). In about half of this group the percentage retention of ${ }^{125} \mathrm{I}_{-} \mathrm{T}_{4}$ on the column was the same as that of the blank (results reported here as $0 \cdot 1 \mu \mathrm{g} / \mathrm{dl}$ ) suggesting a loss in precision in the $0-1 \mu \mathrm{g} / \mathrm{dl}$ range. The Tetralute test, however, showed relatively low results in hyperthyroidism (fig 3 and table I) with a diagnostic discrimination rather worse than that of the resin method (table II) although the group mean was not significantly lower than that obtained by the resin method at the $5 \%$ level. There is a fall off in sensitivity in the method above about 10 $\mu \mathrm{g} / \mathrm{dl}$, seen as a flattening of the standard curve. The manufacturers' recommendation of repeating the assay using $50 \mu \mathrm{l}$ serum instead of the normal $100 \mu \mathrm{l}$ was not followed as this is unattractive economically; it is, however, theoretically sound and could improve the discrimination of thyrotoxicosis.

The older method of estimating serum $\mathrm{T}_{4}$ as the PBI gave a large number of results in the $8-10 \mu \mathrm{g} / \mathrm{dl}$ range in clinically euthyroid patients (fig 4) with a consequent overlap in results with those from thyrotoxic patients (table II): the discrimination was much better for hypothyroidism but the number of patients was small.

Results for $T_{3}$-uptake tests can be expressed in two ways: (1) as a comparison with a normal reference serum, usually human pooled serum, when results can be given as a ratio of test to normal and normal ranges established, provided the percentage uptake of the reference system can be kept within prescribed limits (Howorth, 1970); (2) as a percentage uptake. Uptake systems are timeand temperature-dependent. The Trilute test is reported as a percentage uptake with a reference temperature of $25^{\circ}$, and $1.5 \%$ retention has to be added per degree difference if the room temperature is below $25^{\circ}$ and $1.5 \%$ subtracted per degree difference of room temperature above $25^{\circ}$. The assumption is made that all columns have closely similar elution rates (equivalent to the uptake time in particular resin-uptake tests). As the euthyroid patients had a mean value of $50 \cdot 5$, the values can be converted into the conventional 'percentage of normal' by multiplying by $100 / 50 \cdot 5$. They are then directly comparable with the $T_{4}$-resin uptake. If the conventional values are used to calculate the TriluteTetralute FTI these results become comparable with the reference FTI results (table I).

The Trilute test (equivalent to a $T_{3}$-uptake test) gave better diagnostic discrimination than the reference $T_{4}$-uptake test in both groups, although the difference was slight in hyperthyroidism. In hypothyroidism both tests had group means close to the lower limits of the normal ranges (fig 5 and tables I and II) but the Trilute test was superior to the $T_{4}$-uptake test. As the Trilute test is temperature dependent it is clear that the temperature-correction factor has to be carefully applied in order to minimize 


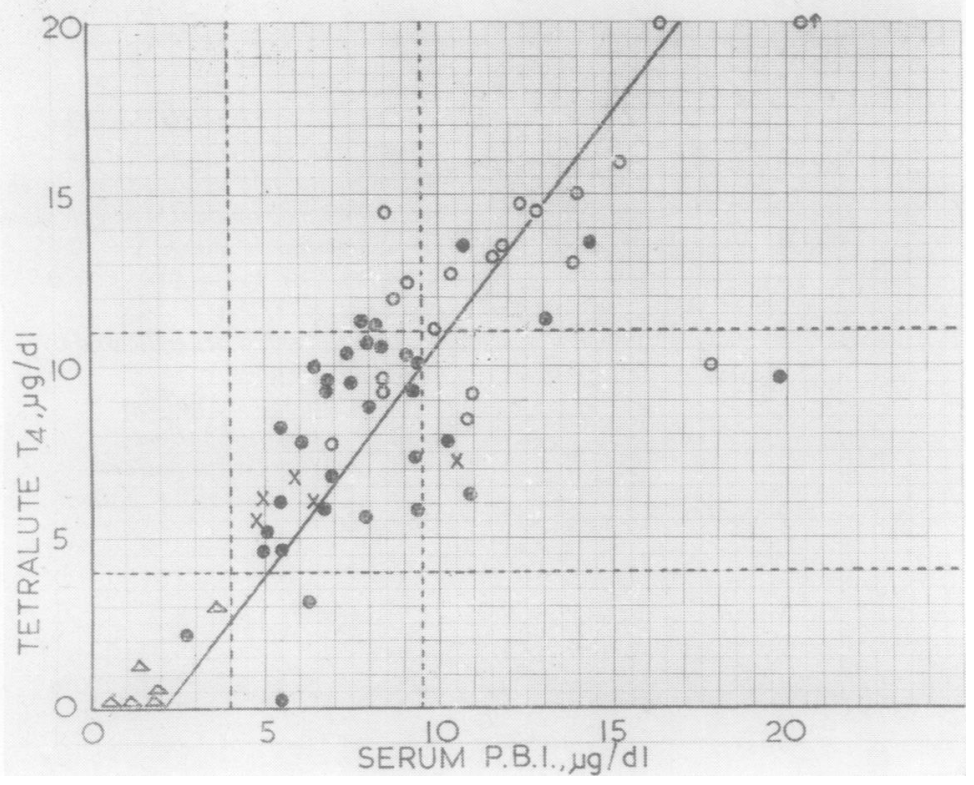

Fig 4 Results for determination of serum total thyroxine by the Tetralute method against serum protein-bound iodine $(P B I)$. The calculated regression line of $x$ on $y$ is shown:

$x=0 \cdot 74 y+2 \cdot 1$,

$S E(x)=2 \cdot 40, r=0.823$, $n=64$.

Symbols and dotted lines as for figure 3 .

overlap in the critical $40-45 \%$ retention zone. We did not find a significant difference in Trilute results between euthyroid men and women outpatients, and our normal limits of $42 \cdot 5-60 \%$ are almost identical with those given by the Ames Company for normal men.

The combination of Trilute and Tetralute measurements to give an FTI is not mentioned by Ames in their instructions for the tests, in spite of the we्dा known advantages of this procedure. In fact mo: than half of the thyrotoxic patients with either normal Tetralute or Trilute test result had an abnormal Trilute-Tetralute FTI, and similarly although $35 \%$ hypothyroid patients had a normal Trilute test result only $12 \%$ had a normal Trilute- $\triangle$ Tetralute FTI (fig 6 and table II). Equally the $\vec{\circ}$

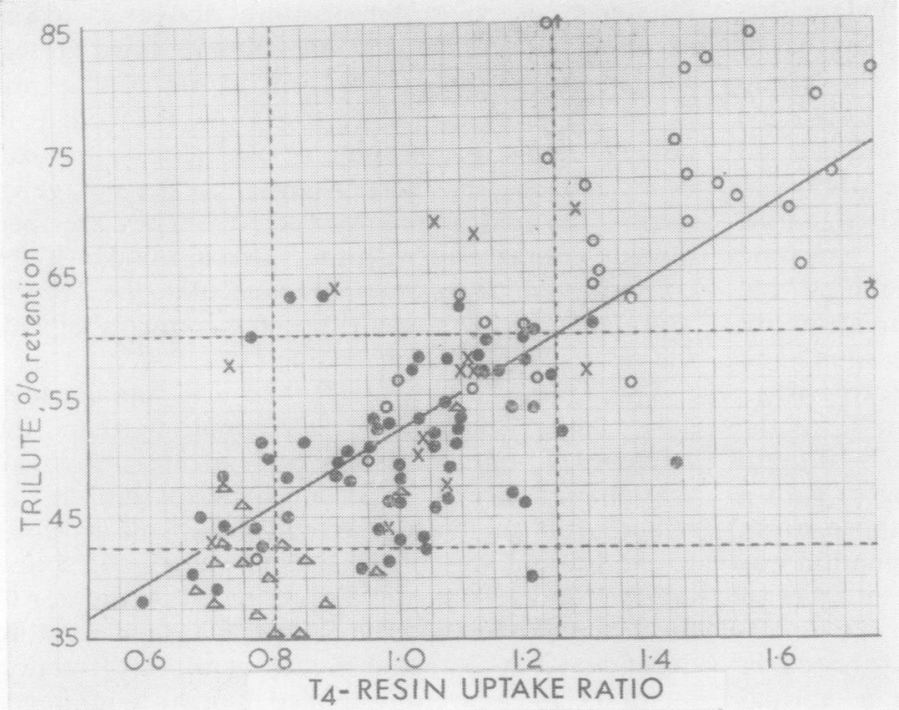

Fig 5 Results for the indirect estimation:of the inverse of serum free TBG capacity as the $\%$ Trilute retention against the reference $T_{4}$-resin uptake method.

The calculated regression line is shown:

$y=31 \cdot 5 x+20 \cdot 4, S E(y)=7 \cdot 87$, $r=0.735, n=126$.

Symbols and dotted line as for figure 3. 


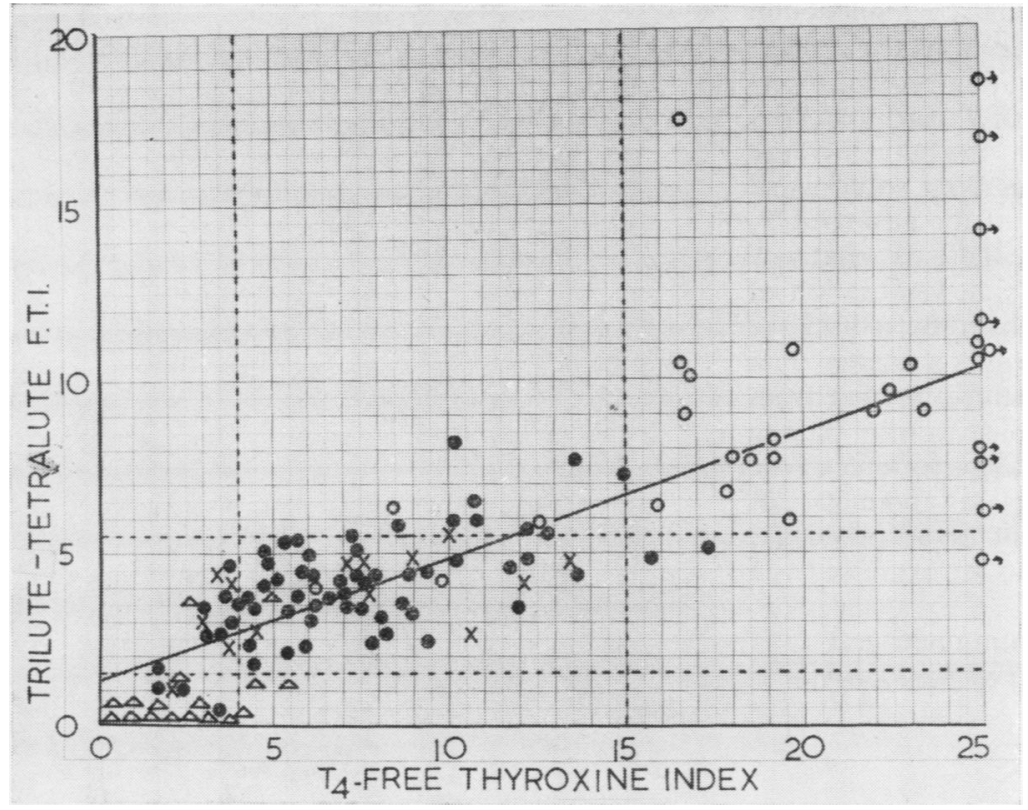

Fig 6 Results for the TriluteTetralute FTI against the $T_{4}-F T I\left(\right.$ serum $T_{4} \times T_{4}$-resin uptake ratio). The calculated regression line is shown: $y=0.35 x+1 \cdot 30$, $S E(y)=1.95, r=0.829$, $n=126$.

Symbols and dotted lines as for figure 3.

Trilute-Tetralute FTI gave mostly normal results in the 'sick euthyroid' patients, most of whom had ischaemic heart disease. This group showed the expected fall in concentration of circulating $T_{4}$ and TBG (rise in Trilute retention; see table I). Because of these changes in the concentration of the thyroxinebinding proteins a mistake in assessment of thyroid status can be made on 'sick euthyroid' patients if only a single test of thyroid function, such as serum $T_{4}$ or $T_{3}$ uptake, is carried out.

Technically the Trilute and Tetralute tests are quicker and easier to perform than the reference resin tests. They were diagnostically superior for hypothyroidism but not for thyrotoxicosis (table II), and of comparable precision (see above). The methods provided to dispense radioactive $T_{3}$ and $T_{4}$ by means of teat droppers or plastic squeeze bottle are somewhat crude and an improved dispensing technique would enable the initial count to be eliminated (Seligson and Seligson, 1972). The replacement of solvent extraction of $T_{4}$ by ' $T_{4}$ stripping' into sodium hydroxide is an important technical improvement whose efficacy in the Tetralute test was confirmed by Braverman et al (1971).

\section{Single Column-free Thyroxine Index}

\section{PRINCIPLE OF THE METHOD}

The test involves a slight modification to the Tetralute serum $T_{4}$ determination. The first two stages are essentially identical (fig 1) except that
$0.3 \mathrm{ml}$ serum is taken initially into $0.5 \mathrm{ml} 0.1 \mathrm{~mol}$ $\mathrm{NaOH}^{-125} \mathrm{I}_{-} \mathrm{T}_{4}$ in the single column-FTI. The third elution stage is different (fig 7); $T_{4}$ and ${ }^{125} \mathrm{I}-\mathrm{T}_{4}$ adsorbed onto the Sephadex is displaced by a mixture of a normal serum preparation ('lyophilized

\section{STAGE 3}

\section{Eluting serum (free TBG) PLUS $20 \mu 1$}

\section{test serum in barbitone $\mathrm{pH} 8.6$}

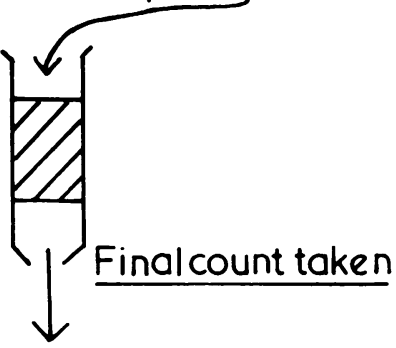

Eluting \& test sera, plus about $50 \%$ adsorbed $T_{4} \&{ }^{125_{1}-T_{4}}$

Fig 7 Outline of the method for the Sephadex $G-25$ single-column free thyroxine index. The first two stages are essentially the same as Sephadex serum $T_{1}$ determination. 
human globuliıs') containing about $1.9 \mathrm{mg}$ globulin and a $20 \mu \mathrm{l}$ aliquot of the serum under test in barbitone buffer $\mathrm{pH} 8 \cdot 6$. The eluting protein therefore contains a varying amount of $T_{4}$ and free TBG according to the thyroid status of the patient whose serum is under test. The test has been so designed that in normal sera about $50 \%$ of the adsorbed $\mathrm{T}_{4}$ is displaced. In thyrotoxicosis there is relatively less displacement owing to the fuller saturation of the test serum TBG, whilst in hypothyroidism the greater amount of free TBG permits a greater than normal displacement of adsorbed $T_{4}$. In sera from pregnant women and euthyroid women taking oestrogen-containing oral contraceptive tablets, the greater amount of free TBG displaces about $50 \%$ of the greater than normal amount of adsorbed $T_{4}$, giving a normal test result. Results are expressed as a ratio

$\frac{\% \text { retention of }{ }^{125} \mathrm{I}-\mathrm{T}_{4} \text { of serum under test }}{\% \text { retention of }{ }^{125} \mathrm{I}-\mathrm{T}_{4} \text { of normal reference serum. }}$

\section{Results}

The single-column FTI was carried out on 45 sera taken from a wide selection of patients referred for assessment of thyroid status including five patients on treatment.

$\begin{array}{lr}\text { Thyrotoxicosis } & \\ \text { Primary diagnosis } & 2 \\ \text { On treatment } & \\ \text { Hypothyroidism } & 6 \\ \text { Primary diagnosis } & 1 \\ \text { On treatment } & \\ \text { Euthyroid patients } & 15 \\ \text { Primary diagnosis } & 3 \\ \text { 'Sick euthyroid' } & 2 \\ \text { On L-T } & 8 \\ \text { On oral contraceptive tablet or pregnant }\end{array}$

Results are given, together with the corresponding results for the two other free thyroxine indices described above, in fig 8 subdivided according to clinical thyroid status. The normal limits were taken as $0.80-1 \cdot 20 ; 18 \%$ euthyroid patients had results below and none had results above these limits, whereas $10 \%$ thyrotoxic and no hypothyroid patients had results inside these limits.

Results on the 37 patients who had all three free thyroxine indices (only the single-column FTI was carried out on the eight euthyroid women who were either pregnant or taking oral contraceptive tablets) were analysed statistically:

Single-column FTI $(y)$ against (i) Trilute/Tetralute FTI $(x) y=0.09 x+0.53, \operatorname{SE}(y)=0.22, \mathrm{r}=0.864$, $\mathrm{n}=37$; (ii) $\mathrm{T}_{4}$-FTI $(x) y=0.04 x+0 \cdot 56, \mathrm{SE}(y)=$ $0 \cdot 24, \mathrm{r}=0 \cdot 828, \mathrm{n}=37$.

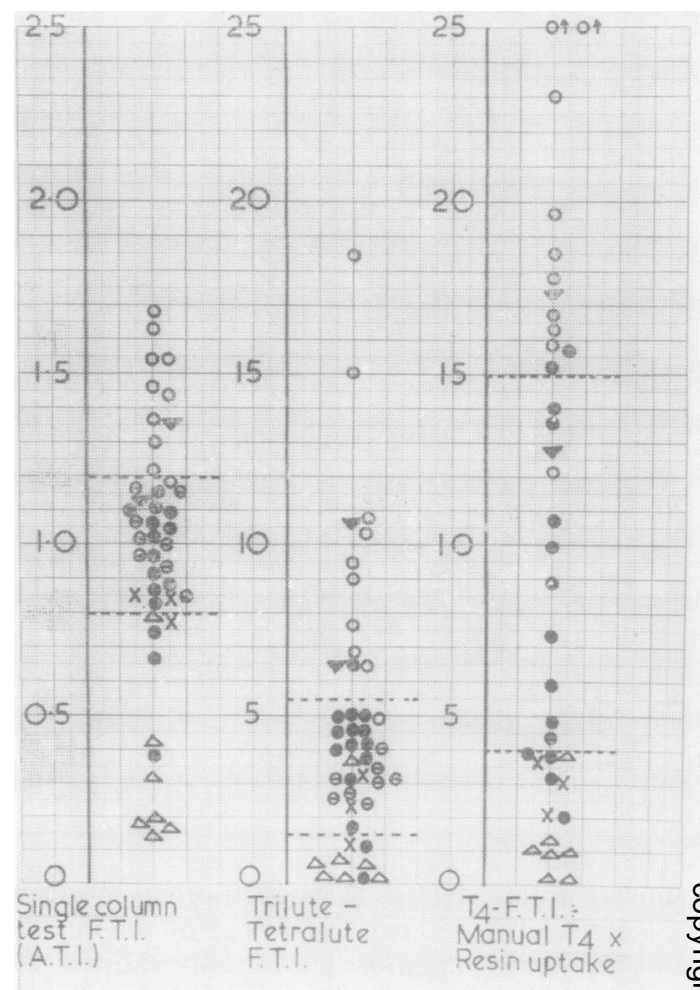

Fig 8 Results for the Sephadex G-25 single-column free thyroxine index compared with those from the Trilute-

Tetralute FTI and the manual reference $T_{4}-F T I$.

$=$ thyrotoxic patient, $\mathbf{0}=$ euthyroid patient ,

$=$ hypothyroid patient $\times=$ 'sick euthyroid' patient, $\vec{\nabla}=$ hypothyroid patient on $L-T_{4} \theta=$ euthyroid women either pregnant or taking oral contraceptive tablets.

Normal range indicated by dotted lines.

The within-batch variation of the single-column FTI was assessed from differences in percentage retention of ${ }^{125} \mathrm{I}-\mathrm{T}_{4}$ on 50 duplicates. The mean retention was $43.1 \%$, SD $1.65, \mathrm{CV} 3.8 \%$. There were insufficient data for an assessment of the between-batch variation for this test.

DISCUSSION ON THE SINGLE-COLUMN FTI The new single-column FTI gave very promising results in this limited trial (fig 8); a fuller trial is required and is planned. It has advantages over the effective thyroxine ratio test (ETR) in that the ETR test is slower (one $\mathrm{hr}$ incubation), requires more serum (more than $1 \mathrm{ml}$ ), and is technically more difficult than the Ames single-column FTI as ethanol extraction of serum and centrifugation is required in 
the ETR test. The single-column FTI is technically slightly easier to perform than the Tetralute serum $\mathbf{T}_{4}$ determination, as a standard curve is not required, but the accurate pipetting of only $20 \mu \mathrm{l}$ serum at one stage is clearly critical. It remains to be seen whether clinicians generally will be willing to use such an index in place of the serum $T_{4}$ or $T_{3}$-uptake test, as there is no point in doing both an uptake test or serum $T_{4}$ and a single-column FTI.

The results obtained by the three free thyroxine indices throw some light onto the question of whether a serum $T_{4}$ level alone is sufficient to screen a patient for thyroid function. The present results suggest that about one euthyroid patient in five will have an abnormal serum $T_{4}$ level, that about one thyrotoxic patient in four, and one hypothyroid patient in three will have a normal serum $\mathbf{T}_{4}$ level, and that this situation can be improved by using either a conventional FTI or the new single-column FTI (results above and table II).

\section{Conclusion}

Three new thyroid function tests in vitro based on commercial kits using columns of Sephadex G-25 have been evaluated and found to be superior to reference methods using resin for the diagnosis of hypothyroidism. Their expense may preclude their use in laboratories which carry out a large number of thyroid function tests in vitro. The present (1973) cost is $72 \mathrm{p} /$ test (Tetralute) and 60p/test (Trilute), but the Ames Thyrimeter gamma counter is lent free if more than 100 tests are done per month. However, the cost and possibly also the precision of the methods may be reduced by using home-made columns and reagents, as in the serum $\mathrm{T}_{4}$ method of Seligson and Seligson (1972). Many other laboratories may adopt one or more of these new tests because of their virtues of simplicity and their diagnostic value, provided that the Tetralute test is repeated on a smaller sample if the $T_{4}$ level is relatively high.

We are indebted to Dr H. K. Watson, Ames Company, for supplying the Trilute and Tetralute kits used in this work, to the staff of the King's College Hospital main computer project for the statistical analyses, and to Dr H. M. B. Buckell, The Maudsley Hospital, SE5, for results for serum PBI.
References

Bauer, R., Schick, L. A., Phillips, B. F., Rupe, C. O., Gross, J., and Gordon, A. (1970). The use of Sephadex G-25 in the estimation of total serum thyroxine. (Abstr.) Clin. Chem., 16, 526.

Braverman, L. E., Vagenakis, A. G., Foster, A. E., and Ingbar, S. H. (1971). Evaluation of a simplified technique for the specific measurement of serum thyroxine concentration. J. clin. Endocr., 32, 497-502.

Clark, F., and Horn, D. B. (1965). Assessment of thyroid function by the combined use of the serum protein-bound iodine and resin uptake of ${ }^{131}$ I-triiodothyronine. J. clin. Endocr., 25, 39-45.

Cuarón, A., and Fucugauchi, M. E. (1964). The binding of ${ }^{131} \mathrm{I}-$ triiodothyronine by serum proteins as an in vitro test of thyroid function. Acta endocr. (Kbh.), 46, 161-169.

Gelotte, B. (1960). Studies on gel filtration; sorption properties of the bed material Sephadex. J. Chromatogr., 3, 330-342.

Gimlette, T. M. D. (1967). Use of Sephadex column chromatography in the assessment of thyroid status. J. clin. Path., 20, 170-179.

Hansen, H. H. (1966). Sephadex binding of ${ }^{131}$ I-labelled L-triiodothyronine as a test of thyroid function. Scand. J. clin. Lab. Invest. 18, 240-244.

Howorth, P. J. N. (1970). Assessment of thyroid function by the combined estimation of serum total thyroxine and resin uptake of ${ }^{125}$ I-thyroxine. M.D. Thesis, Cambridge University, pp. 168179.

Howorth, P. J. N., and Maclagan, N. F. (1969). Clinical application of serum total thyroxine estimation, resin uptake, and free thyroxine index. Lancet, 1, 224-228.

Lee, N. D., Henry, R. J., and Golub, O. J. (1964). Determination of the free thyroxine content of serum. J. clin. Endocr., 24, 486495.

Liewendahl, K., and Lamberg, B. A. (1965). Free thyroxine in serum determined by dialysis and Sephadex G-25 filtration. J. clin. Endocr., 25, 991-993.

Lissitzky, S., and Bismuth, J. (1963). Determination quantitative de la composition du serum en ${ }^{131}$ I-thyroxine et ${ }^{131}$ I-triiodothyronine par filtration sur gel de dextrane (Sephadex). Clin. chim. Acta, 8, 269-276.

Maclagan, N. F., and Howorth, P. J. N. (1969). Thyroid function studies using resin uptake of radioactive thyronines from serum and total thyroxine assay: the free thyroxine index. Clin. Sci., 37, 45-60.

Mincey, E. K., Thorson, S. C., and Brown, J. L. (1971). A new in-yitro blood test for determining thyroid status-the effective thyroxine ratio. Clin. Biochem., 4, 216-221.

Mougey, E. H., and Mason, J. W. (1963). Separation of some iodoamino acids and iodide by gel filtration. Analyt. Biochem., 6, 223-233.

Murphy, B. E. P., and Pattee, C. J. (1964). Determination of thyroxine utilizing the property of protein-binding. J. clin. Endocr., 24, 187-196.

Murphy, B. E. P., Pattee, C. J., and Gold, A. (1966). Clinical evalua tion of a new method for the determination of serum thyroxine J. clin. Endocr., 26, 247-256.

Osorio, C., Jackson, D. J., Gartside, J. M., and Goolden, A. W. G. (1962). The assessment of free thyroxine in plasma. Clin. Sci., 23, 525-530.

Porath, J., and Flodin, P. (1959). Gel filtration: a method for desalting and group separation. Nature (Lond.), 183, 1657-1659.

Seligson, H., and Seligson, D. (1972). Measurement of thyroxine by competitive protein binding. Clin. chim. Acta, 38, 199-205.

Shapiro, B., and Rabinowitz, J. L. (1962). A chromatographic method utilizing Sephadex for the separation of free iodide, proteinbound and unbound triiodothyronine in sera. J. nucl. Med., 3, 417-421. 